\title{
The Role of Argyrophilic Nucleolar Organizer Region (AgNOR) Study in Cytological Evaluation of Fluids, Especially for Detection of Malignancy
}

\author{
Karki S, Jha A, Sayami G
}

Department of Pathology

IOM, TUTH, Kathmandu, Nepal

\begin{abstract}
Background

Serous effusion smears reported as "suspicious for malignancy" pose problems in clinical management. Silver staining for argyrophilic nucleolar organizer regions (AgNOR) has proved useful in making a cytopathologic differential diagnosis between benign and malignant cells. Nucleolar organizer regions(NORs) are loops of DNA located in acrocentric chromosomes. These NORs are visualized by silver staining technique that recognizes these argyrophilia associated proteins which are increased in malignancy.
\end{abstract}

Department of Pathology

TUTH, Maharajgung

Kathmandu, Nepal.

email: shovana_karki@hotmail.com

\section{Objective}

This study aimed to distinguish reactive mesothelial cells from malignant cells in serous effusions using these NORs.

\section{Methods}

\section{Citation}

Karki S, Jha A, Sayami G.The Role of Argyrophilic Nucleolar Organizer region (AgNOR) Study in Cytological Evaluation of Fluids, Especially for Detection of Malignancy. Kathmandu Univ Med J 2012;37(1):447.

A total of 174 serous effusions received at the Department of Pathology, TUTH, during a period of one year were included in the study. Smears were studied by conventional Papanicolaou and Giemsa stains. AgNOR counts, variation in size and dispersion of AgNOR dots in smears were graded and compared in malignant and non-malignant effusions.

\section{Results}

Mean AgNOR counts of $10.43 \pm 0.73$ and $10.21 \pm 0.51$ in malignant peritoneal and pleural effusions, respectively, were significantly $(p<0.0001)$ greater as compared with counts of $2.12 \pm 0.54$ and $2.11 \pm 0.54$ in non-malignant effusions. The AgNORs were irregular in shape in malignant effusions whereas they were comparatively larger, single dots in benign effusions. AgNOR size and dispersion were of higher grade in significantly greater proportion of malignant as compared with non malignant effusions $(p<0.0001)$. Of the cytologically suspicious samples, nine were in the malignant range and one was in the benign range.

\section{Conclusion}

AgNOR study appears to be clinically useful as an additional diagnostic tool for use in serous effusion when the cytologic diagnosis is difficult.

\section{KEY WORDS}

AgNOR, cytology, effusions

\section{INTRODUCTION}

Serous effusion is often the first clinical manifestation of malignant tumor or their metastatic counterparts. In one third of the malignant effusions, cytology often gives the first indication of malignancy. ${ }^{1}$ The cytological examination of effusion is therefore of great clinical importance. An accurate identification of tumor cells in pleural and peritoneal fluids is a well known diagnostic challenge. ${ }^{2}$ Particularly differentiating some inflammatory cells, hyperplastic mesothelial cells, neoplastic mesothelial cells and cells of metastatic adenocarcioma, due to their cytological similarity, sometimes becomes impossible. ${ }^{3}$

Sensitivity of conventional cytology for the detection of malignant cells varies from 50-78\%.4-5 Ancillary diagnostic methods have been proposed to increase the diagnostic accuracy for detection of malignant cells..$^{4-6} \mathrm{~A}$ comparatively simple technique used for this purpose is the silver staining of the nucleolar organizer region (AgNOR). 
AgNOR staining is a technique to detect the argyrophilia of the nucleolar organizer regions (NORs) - related proteins. NORs are loops of ribosomal DNA responsible for the transcription of ribosomal RNA on the short arm of acrocentric human chromosomes. ${ }^{7}$

They play a role in protein synthesis. Two argyrophilic proteins are nucleolin and nucleophosmin. ${ }^{8}$ These argyrophilic proteins are stained by silver stains after which they can be identified as black dots present throughout the nucleolar area. The number and size of the NORs reflect cell activity and proliferation and help to distinguish benign from malignant cells. ${ }^{9}$

In the present study, this technique has been applied to differentiate malignant cells from reactive mesothelial cells in pleural and peritoneal effusions.

\section{METHODS}

This is a prospective study in which 174 cases of serous effusions received in the Department of Pathology, Institute of Medicine, TUTH, during the study period were studied. The effusion fluids were centrifuged and deposit smeared on the slide. The cytological smears were studied by conventional Papanicolaou and Giemsa stains and the diagnosis of malignancy or otherwise were made. AgNOR counts, variation in size and dispersion of AgNOR dots in smears were graded and compared in malignant and non malignant effusions as per the criteria devised by Ahsan et al. ${ }^{10}$

\section{Counting of AgNOR dots:}

AgNORs were counted in 100 nuclei of mesothelial or neoplastic cells in benign and malignant effusions respectively, under $100 x$ oil immersion lens under light microscope. The mean AgNOR count was then recorded.

Distribution of AgNORs in the nuclei were graded as

$0=$ limited to the nuclei.

$1+=$ occasional dispersion outside nucleoli.

$2+=$ Moderate dispersion outside nucleoli.

$3+=$ widely dispersed throughout the nucleus.

Size variation was graded as

$0=$ more or less uniform in size.

$1+=$ two different sizes.

$2+=$ more than two different sizes.

$3+=$ all grades and sizes including too minute to be counted.

The SPSS version 10.0 software was used to analyse data. Comparison of the data was carried out by the non parametric Mann-Whitney $U$ test and the Kruskal Wallis test. For AgNOR count Chi-Square test was performed. A value of $p<0.05$ was considered significant.

\section{RESULTS}

During the one year period, 174 cases included in the study constituted 103 (59.2\%) peritoneal and 71 (40.8\%) pleural fluids. In the former, age ranged from 1- 95 years (mean 48.3) and in the later, it ranged from 1- 88 years (mean 52.7). Male: Female in case of peritoneal fluid was 1:1.5 whereas in pleural fluid the ratio was 1.4:1.

According to the cytomorphology of the cells in fluids, 80 cases were benign, 16 malignant and 7 were suspicious in peritoneal fluids whereas 52, 16 and 3 cases were benign, malignant and suspicious, respectively in pleural effusions.

Metastasis from primary organ site is illustrated in Table 1. AgNOR count, size and didtribution are displayed in Table 2, Table 3 and Table 4, respectively.

Table 1. Distribution of primary organ site in 32 cases of malignant effusions.

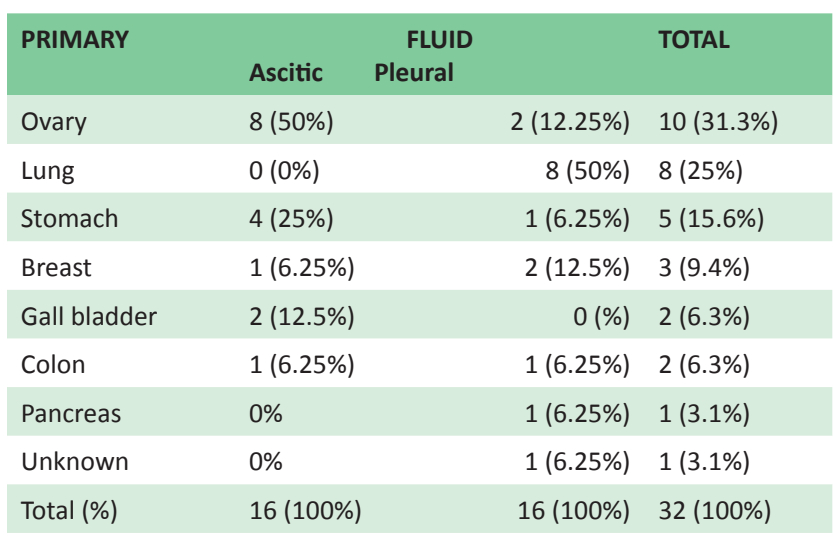

Table 2. Comparison of AgNOR counts in non malignant, malignant and suspicious effusions in peritoneal and pleural fluids.

\begin{tabular}{|c|c|c|c|c|c|}
\hline \multicolumn{2}{|c|}{ Nature of effusion } & \multicolumn{4}{|c|}{ AgNOR counts } \\
\hline & & Range & Me & & $\pm S D$ \\
\hline \multirow{3}{*}{ 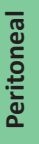 } & Benign & $1.23-3.88$ & 2.12 & \pm 0.54 & \\
\hline & Malignant & $9.55-12.02$ & 10.43 & \pm 0.73 & \\
\hline & Suspicious & 2.04-10.09 & 8.77 & \pm 2.97 & \\
\hline \multirow{3}{*}{$\begin{array}{l}\overline{\frac{\pi}{3}} \\
\frac{0}{\alpha}\end{array}$} & Benign & $1.28-3.23$ & 2.11 & \pm 0.54 & \\
\hline & Malignant & $9.32-11.02$ & 10.21 & \pm 0.51 & \\
\hline & Suspicious & $10.98-11.22$ & 11.06 & \pm 0.13 & \\
\hline
\end{tabular}

\section{DISCUSSION}

A wide variety of abnormalities and insults can produce serous effusions in patients without cancer. In vast majority of the cases the cellular response is quite non specific and will show varying proportions of mesothelial cells, macrophages, erythrocytes, lymphocytes, neutrophils and other leucocytes. However, the most significant role of cytopathology is in the examination of effusion fluid for the presence of cancer cells. Many studies report on the frequency and accuracy of cytopathologic detection of cancer cells in effusions drawn from patients with known malignancy. ${ }^{11-12}$ In such studies most common 
Table 3. Comparison of AgNOR size in benign, malignant and suspicious effusions.

\begin{tabular}{|c|c|c|c|c|c|c|}
\hline \multirow{3}{*}{$\begin{array}{l}\text { Nature of } \\
\text { effusion }\end{array}$} & \multicolumn{3}{|c|}{$\begin{array}{l}\text { Cases of peritoneal effu- } \\
\text { sions }\end{array}$} & \multicolumn{3}{|c|}{ Cases of pleural effusions } \\
\hline & AgNOR & size & $\begin{array}{l}\text { Total no } \\
\text { of cases }\end{array}$ & AgNOR & size & $\begin{array}{l}\text { Total } \\
\text { no of } \\
\text { cases }\end{array}$ \\
\hline & 0 to $1+$ & $\begin{array}{l}2 \text { to } \\
3+\end{array}$ & & 0 to $1+$ & $\begin{array}{l}2 \text { to } \\
3+\end{array}$ & \\
\hline $\begin{array}{l}\text { Non ma- } \\
\text { lignant }\end{array}$ & 78 & 2 & 80 & 51 & 1 & 52 \\
\hline Malignant & 3 & 13 & 16 & 2 & 14 & 16 \\
\hline $\begin{array}{l}\text { Suspi- } \\
\text { cious }\end{array}$ & 1 & 6 & 7 & 0 & 3 & 3 \\
\hline Total & 82 & 21 & 103 & 53 & 18 & 71 \\
\hline $\begin{array}{l}\text { Compari- } \\
\text { son }\end{array}$ & \multicolumn{3}{|c|}{$P<0.0001$} & \multicolumn{3}{|c|}{$P<0.0001$} \\
\hline
\end{tabular}

tumors in pleural effusions were adenocarcinoma and lymphoreticular diseases. Squamous cell carcinoma, although very common primary neoplasm of lung, was recognized in much less frequency $(5 \%) .{ }^{13}$ In this study all metastatic tumors to pleural and peritoneal fluids were adenocarcinomas.

Koss has summarized extensively the literature reporting tumor incidences in effusions of all types. He has reported the origin of malignant neoplasm in pleural effusions in both the sexes. In order of descending frequency, in the male, lung, gastrointestinal tract and malignant lymphoma; and among female, breast, ovary, gastrointestinal tract, lung \& malignant lymphoma are the common primary sites. ${ }^{13-14}$ This study is in agreement with those of Koss. In this study lung was the commonest origin of malignant pleural effusion in males and breast was the commonest origin of malignant pleural effusion in females. In peritoneal effusion the commonest site of primary in females was the ovary. This is in accord with the study of Bjorn et al. ${ }^{15}$ Ovarian neoplasms of epithelial origin constituted a large part of malignant effusions in the study carried out by Zachon et al. ${ }^{16}$

According to the results of various studies, malignancy accounts for $40 \%$ of all pleural effusions. ${ }^{17-18}$ Percentage of malignant pleural and peritoneal effusions was $22.5 \%$ and $15.5 \%$ respectively in the present study.

Male to female ratio in pleural effusion reported by Sharma et al was 1.14:1 and a slight male predominance was reported by Golshan et al. ${ }^{19,20}$ In the present study, the male to female ratio for pleural effusion was 1.4:1 and for peritoneal fluid it was 1:1.5 which supports the previous studies.

In the present study, majority of the patients with pleural effusions were in the age group 71-80 years and peritoneal effusions 41-50 years. But the maximum number of malignancy was seen in 41-50 years of age followed by 51-60 years. Sharma et al reported maximum number of effusions in the range $41-60$ years. ${ }^{19}$

A distinct qualitative difference in AgNOR count between
Table 4. Comparison of AgNOR distribution in peritoneal and pleural fluids.

\begin{tabular}{|c|c|c|c|c|c|c|}
\hline \multirow{3}{*}{$\begin{array}{l}\text { Nature of } \\
\text { effusion }\end{array}$} & \multicolumn{3}{|c|}{$\begin{array}{l}\text { Cases of peritoneal effu- } \\
\text { sions }\end{array}$} & \multicolumn{3}{|c|}{ Cases of pleural effusions } \\
\hline & $\mathrm{AgNOR}$ & $\begin{array}{l}\text { disper- } \\
\text { sio }\end{array}$ & $\begin{array}{l}\text { Total } \\
\text { no of } \\
\text { cases }\end{array}$ & $\mathrm{AgNOR}$ & $\begin{array}{l}\text { dis- } \\
\text { persio }\end{array}$ & $\begin{array}{l}\text { Total } \\
\text { no of } \\
\text { cases }\end{array}$ \\
\hline & 0 to $1+$ & 2 to $3+$ & & 0 to $1+$ & $\begin{array}{l}2 \text { to } \\
3+\end{array}$ & \\
\hline $\begin{array}{l}\text { Non ma- } \\
\text { lignant }\end{array}$ & 77 & 3 & 80 & 48 & 4 & 52 \\
\hline Malignant & 2 & 14 & 16 & 2 & 14 & 16 \\
\hline $\begin{array}{l}\text { Suspi- } \\
\text { cious }\end{array}$ & 2 & 5 & 7 & 0 & 3 & 3 \\
\hline Total & 81 & 22 & 103 & 50 & 21 & 71 \\
\hline $\begin{array}{l}\text { Compari- } \\
\text { son }\end{array}$ & \multicolumn{3}{|c|}{$P<0.0001$} & \multicolumn{3}{|c|}{$P<0.0001$} \\
\hline
\end{tabular}

benign mesothelial and malignant cells was seen in this study. Mean \pm SD AgNOR count in benign mesothelial cells in pleural and peritoneal effusions was $2.11 \pm 0.54$ and $2.12 \pm 0.54$ respectively. While the malignant cells in pleural and peritoneal effusions had mean \pm SD AgNOR count $10.21 \pm 0.51$ and $10.43 \pm 0.73$ respectively. This study is in accord with several studies performed on AgNOR count on different effusions which show that AgNOR study may be useful in the differential diagnosis of benign and malignant effusions. $^{21,22}$ So AgNOR count appears as an important additional diagnostic tool for use in ascitic and pleural fluid samples when routine cytological diagnosis is difficult. ${ }^{23}$ Other co-workers have also documented that AgNOR count is higher in malignant than in benign mesothelial cells. ${ }^{24}$

Following the criteria devised by Ahsan et al in the present study, it was found that in addition to the high number of AgNOR counts, AgNOR distribution was irregular and had a grade of $2+$ to $3+$ in the majority of the malignant effusions. ${ }^{10}$ On the other hand, mesothelial cells had regularly clustered AgNORs and a distribution grade of 0 to $1+$ in most of the cases. Similarly, Akhtar et al graded AgNOR dispersion in effusions and found that AgNORs were less dispersed in non malignant than in malignant effusions. ${ }^{25}$ This finding correlates with the present study.

AgNORs were heterogeneous in size and graded $2+$ to $3+$ in most malignant cases. Whereas, they were homogeneously sized in non malignant effusions and graded 0 to $1+$. This is in agreement with the study carried out by Gul Naz et al. ${ }^{26}$

The difference between the size and dispersion in malignant and non malignant effusions was statistically significant. These parameters are easy to use and give reproducible results. These parameters of AgNOR typing were described by authors in cases of prostate and have subsequently been used in diseases of liver and effusions. 10,26,27

Three cases of suspicious pleural effusions had lung adenocarcinoma diagnosed on FNAC. Similarly, out of seven suspicious peritoneal effusions four were diagnosed as ovarian serous cystadenocarcinoma on biopsy, 2 were diagnosed as gastric adenocarcinoma on biopsy and 1 as 
colonic adenocarcinoma on FNAC. In the present study, 9 out of the 10 cytologically diagnosed suspicious cases had high AgNOR counts and higher AgNOR size and dispersion grade as well as high proliferative index. Hence, AgNOR is depicted as a useful technique is detecting malignant cells in effusions.

Mohanty et.al conducted a study to access the AgNOR count using manual and automated methods. No significant differences were seen in the counts when these two methods were used. ${ }^{28}$ Though automated AgNOR counting is rapid and less cumbersome, manual method can still be utilized in the set up, like ours, were automated counting is expensive and thus mostly out of reach

\section{CONCLUSION}

Thus AgNOR study appears to be clinically useful as an additional diagnostic tool for use in serous effusion when the cytologic diagnosis is difficult.

\section{REFERENCES}

1. Bedrossian CWM. Malignant effusions. A multimodal approach to cytologic diagnosis. New York and Tokyo:Igaku-Shoin Medical Publishers 1994; 9-17.

2. Tiniakos DG, Healicon RM, Hair T, Wadehra V, Horne CH, Angus B. P53 immunostaining as a marker of malignancy in cytologic preparation of body fluids. Acta Cytol 1995; 39:171-6.

3. Van de Molengraft FJJM, Van't Hof MA, Herman CJ, Voojis TG. Quantative light microscopy of atypical mesothelial cells and malignant cells in ascitic fluid. Anal Quant Cytol 1981; 4:217-20.

4. Lee JS, Lee MS, Park CS, Junng SW. Diagnostic value of p53 protein and flow cytometric DNA analysis in the study of serous effusion. Acta Cytol 1997; 41:1719-25.

5. Queiroz C, Barrel-Netto M, Bacchi CE. Characterizing subpopulations of neoplastic cells in serous effusions: the role of immunocytochemistry. Acta Cytol 2001; 45: 18-22.

6. Davidson B, Risberg B, Keistensen G, Kvalheim G, Emilson E, Bjaner A. Detection of cancer cells in effusions from patients with gynecological malignancies: evaluation of five epithelial markers. Virchows Arch 1999; 435: 43-9.

7. Ferguson- Smith MA, llandmaker SD. Observations on the satellited human chromosomes. Lancet 1961;1:638-40.

8. Derenzini M. The AgNORs. Micron 2000;31(2):117-120.

9. Rocher A, Blanco AM, Palaoro L. Usefulness of AgNOR assay in the assessment of serous effusions. Sociedad Medica de Santiago 2000; 128(9):963-6812.

10. Ahsan S, Tayyab M, Chaudrhy NA, Khan SA. Silver staining nucleolar organizer region (AGNOR) typing in nodular hyperplasia and carcinoma of prostate. Pak Postgrad Med J 1991-1992;2-3:67-72.

11. Murphy WM, Ng AB. Determination of primary site by examination of cancer cells in body cavity.fluid. Am J Clin Pathol 1972;58:479-88.

12. Spriggs Al, Boddington MM. The cytology of effusions. New York: Grune and Stratton 1968; 12-40.

13. William $W$, Johnston. The malignant pleural effusion. A review of cytopathologic diagnosis of 584 specimens from 472 consecutive patients. Cancer 1985;56:905-9.

14. Koss Lg. Diagnostic cytology. Philadelphia. J.P. Lippincott 1979; 878965.
15. Bjorn R, Ben D, Hiep P Dong. Flow cytometric immunophenotyping of serous effusions and peritoneal washing comparison with immunocytochemistry and morphological findings. J Clin Pathol 2000;53:513-7.

16. Zachon K, Tzartza E, Skenteri A, Orologa A. Ascitic fluid, peritoneal washing and cul de sac aspiration cytology in women under the age of 40: a retrospective study. Cytopathology 2004;15:14-7.

17. Tinney WS, Olsen AM. The significance of fluid in the pleural space: A study of 274 cases. Maya Clin Proc 1945;20:81-5.

18. Leuallen EC, Carr DT. Pleural effusion: A statistical study of 436 patients. N Eng J Med 1955;252:79-83.

19. Sharma D. Comparison of methods to improve the quality of smears in blood cell samples of serous fluids. Dept of Pathol Govt Medical College, Amritsar Baba Farid University of Health Science, Faridkot 2000. (PubMed).

20. Golshan M, Faghihi M, Ghanbarian K. Common causes of pleural effusion in referral hospital in Isfahan, Iran 1997-1998. Asian Cardiovasc Thorac Ann 2002;10:43-6.

21. Jiang $S$, Zeng $Z$, Liao Z. Study on the diagnostic value of analyzing argyrophilic nucleolar organizer region in benign and malignant effusions. Zhonghua. Jie He He Hu Xi za Zhi 1998;21(1):34-6.

22. Lin MS, Choing IW. Nucleolar organizer regions in smears of pleural effusion. Gaoxiong Yi Xue Ke Yue Za Zhi 1994 Jan;10(1);16-21

23. SujathanK, Kannan S. Significance of Ag NOR count in differentiating malignant cells from reactive mesothelial cells in serous effusions. Acta Cytol 1996;40:724-8.

24. Khalid A W, KSA. Silver staining nucleolar organizer region (AgNOR) counts in benign and malignant effusions. Pak Postgrad Med J 1996;7(3-4):54-6.

25. Khan SA, Ahmed N, Khalid AW, Akhtar GN. Patterns of AgNOR in pleural and peritoneal effusions. JCPSP 2006;16:412-415.

26. Akthar GN, Chaudry NA, Tayyab M, Khan SA. AgNOR staining in malignant and benign effusions. Pak J Med Sci 2004;20(1);29-32.

27. Parveen S. p53 and AgNORs in normal, cirrhotic and carcinomatous liver. (Thesis.) Lahore University. Punj 2000.

28. Mohsanty SK, Dey P, Rana P. Manual and automated AgNOR count in differentiating reactive mesothelial from metastatic malignant cells in serous effusions. Anal Quant Cytol Histol 2003;25(5):273. 